
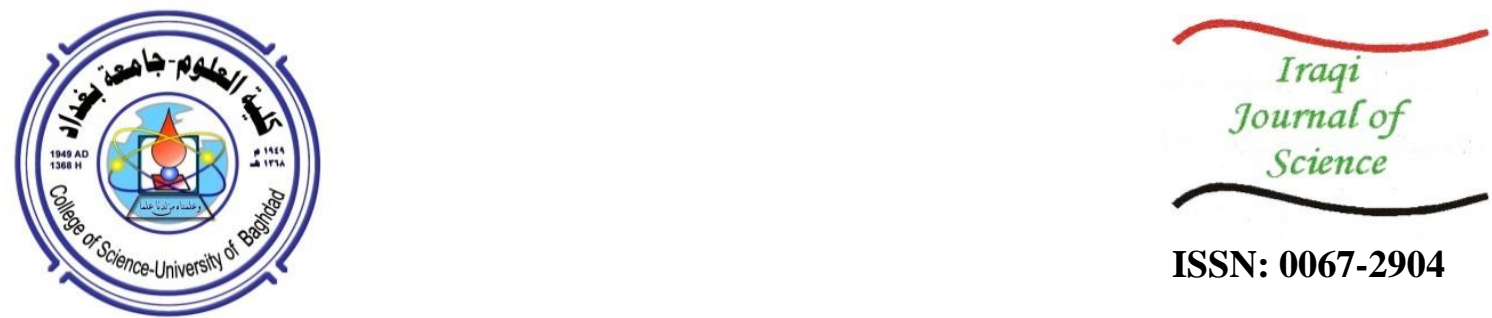

ISSN: 0067-2904

\title{
An Integrated Microfacies and Well Logs-Based Reservoir Characterization of Yamama Formation, Southern Iraq
}

\author{
Mohanad M. Al-Ghuribawi*, Rasha F. Faisal \\ Department of Geology, College of Science, University of Baghdad, Baghdad, Iraq
}

Received: $17 / 11 / 2020$

Accepted: 21/12/2020

\begin{abstract}
The Yamama Formation includes important carbonates reservoir that belongs to the Lower Cretaceous sequence in Southern Iraq. This study covers two oil fields (Sindbad and Siba) that are distributed Southeastern Basrah Governorate, South of Iraq. Yamama reservoir units were determined based on the study of cores, well logs, and petrographic examination of thin sections that required a detailed integration of geological data and petrophysical properties. These parameters were integrated in order to divide the Yamama Formation into six reservoir units (YA0, YA1, YA2, YB1, YB2 and YC), located between five cap rock units. The best facies association and petrophysical properties were found in the shoal environment, where the most common porosity types were the primary (interparticle) and secondary (moldic and vugs). The main diagenetic process that occurred in YA0, YA2, and YB1 is cementation, which led to the filling of pore spaces by cement and subsequently decreased the reservoir quality (porosity and permeability). Based on the results of the final digital computer interpretation and processing (CPI) performed by using the Techlog software, the units YA1 and YB2 have the best reservoir properties. The unit YB2 is characterized by a good effective porosity average, low water saturation, good permeability, and large thickness that distinguish it from other reservoir units.
\end{abstract}

Keywords: Yamama Formation, Reservoir units, Microfacies, Depositional environment, Well logs, Southern Iraq.

وصف متكامل للخصائص المكمنية لتكوين اليمامة، بالاعتماد على السحنات الاقيقة ومجسات الابار،

$$
\text { جنوب العرلق }
$$

\footnotetext{
مهند تحمد حسين الغريباوي *، رشا فوزي فيصل

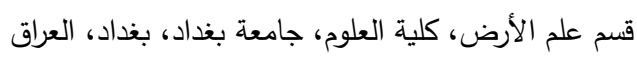

الخلاصة

تكوين اليمامة يتضمن على اهم المكامن الكاربونايتية التي تنتمي الى العصر الطباشيري السفلي، في

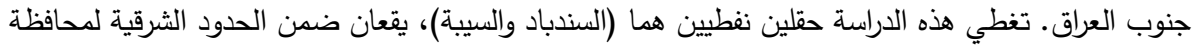

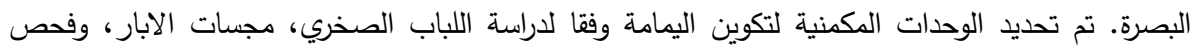

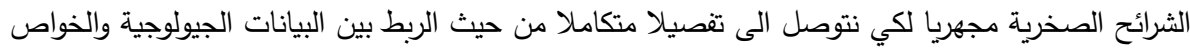

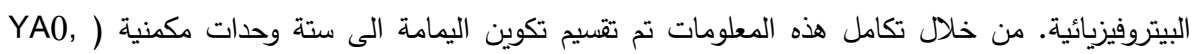

*Email: mohanadalmystro@gmail.com 


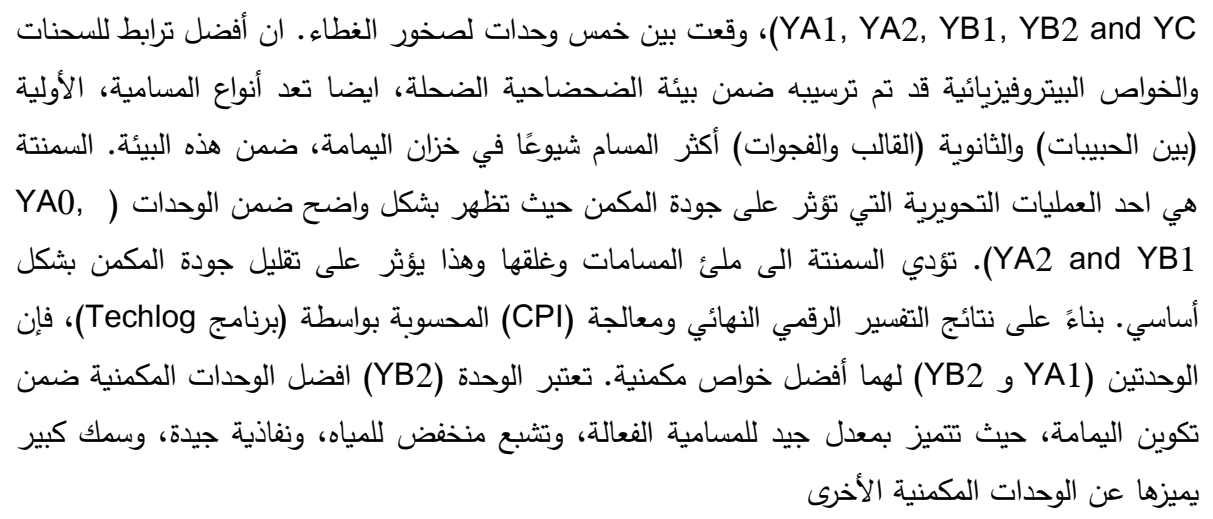

\section{Introduction}

Lower Cretaceous carbonate rocks of Yamama Formation represent one of the most important oil reservoirs in Southern Iraq. Yamama Formation belongs to the late Berriasian Aptian cycle. This cycle is characterized by shore to deep basin with the Zubair, Ratawi, Garagu, Yamama, Shuiaba, Sarmord, and Lower Balambo formations. Microfacies analysis is a useful tool for the prediction of porosity origin and permeability. In addition, diagenetic processes are responsible for modifications in primary characteristics. Within microfacies analysis, depositional environments and diagenetic processes of the Yamama Formation can be determined. Especially, direct observations which include depositional textures, diagenetic alterations, constituent composition, and pore characteristics can give the foundation for reservoir descriptions [1]. These interpretations help to predict the size, shape, and other rock properties, such as porosity and permeability.

Reservoir characterization is mainly concerned with the physical properties of reservoir and fluid. Well logging is an essential tool in the evaluation of formations. An integration of reservoir facies description (microfacies) and reservoir characterization (petrophysical properties) enhances the interpretation of reservoir geology.

The area of the present study is located in Basrah Governorate, Southern Iraq, including Sindbad and Siba oilfields. The first oil field is located approximately $18 \mathrm{~km} \mathrm{SE}$ and the second is $30 \mathrm{~km} \mathrm{SE}$ of Basrah City (Figure 1). Thickness values of selected wells are shown in Table 1. The area is dominated by Quaternary sediments, such as marsh and fluvial deposits [2]. 


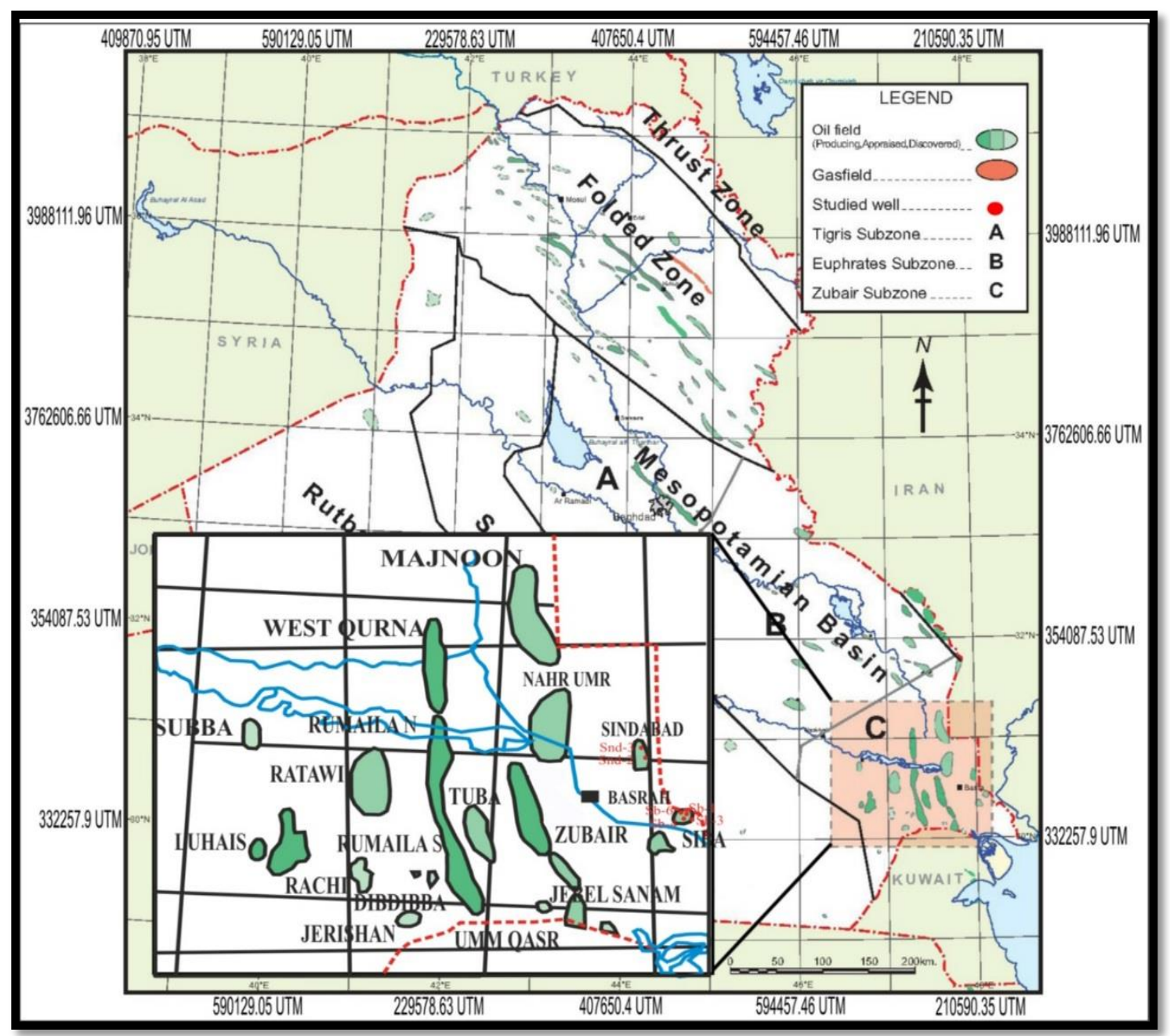

Figure 1- Location map of the study area, modified after [3].

Table 1-Thickness of Yamama Formation and geographic coordinates of studied wells in Sindbad and Siba oilfields

\begin{tabular}{|c|c|c|c|c|c|c|}
\hline Field name & Well ID & Easting & Northing & $\begin{array}{c}\text { Top (m) } \\
\text { R.T.K.B }\end{array}$ & $\begin{array}{c}\text { Bottom } \\
(\mathbf{m}) \\
\text { R.T.K.B }\end{array}$ & $\begin{array}{c}\text { Thickness } \\
(\mathbf{m})\end{array}$ \\
\hline Sindbad & Snd-2 & 787500 & 3389000 & 4020 & 4338 & 318 \\
\hline Sindbad & Snd-3 & 786740 & 3390730 & 4019 & 4336 & 317 \\
\hline Siba & Sb-1 & 799064 & 3368717.5 & 3891 & 4173.8 & 282.8 \\
\hline Siba & Sb-3 & 803400 & 3367150 & 4009.3 & 4242 & 232.3 \\
\hline Siba & Sb-4 & 798830 & 3368289 & 3905 & 4235 & 330 \\
\hline Siba & Sb-6 & 2216000 & 33687000 & 3906 & 4100 & 194 \\
\hline
\end{tabular}

\section{Data and Methods}

More than 360 core samples of Yamama Formation were collected from four wells. Five well logs were examined, including gamma ray (GR), sonic (DT), density, neutron, and resistivity (LLD) logs. Cores were utilized to provide an accurate representation of lithofacies to infer sedimentary processes and depositional systems. In addition, cores were used to calibrate well $\operatorname{logs}$ in order to identify representative well log signatures of each lithology. The petrographic study permitted centimeter to micrometer scale assessment of rock properties. The study included observations of rock composition, texture, and fossils of cores, using naked eyes and thin-section microscopy. The results were used to interpret depositional 
systems. Well log analysis involved a centimeter to meter scale examination of rock properties. Core-calibrated $\log$ analysis focused on interpretation and delineation of lithofacies and depositional systems. In addition, well logs provided information for the determination effective porosity, clay volume, and water saturation. Techlog software V.3 2015 was used in well log analysis and interpretation.

\section{Geological setting}

\section{a. Tectonic setting}

The Yamama basin is located in the Arabian plate, Mesopotamian zone (Zubair subzone) [4]. This study included Sindbad and Siba oilfields, located within the Basrah subzone in the eastern part of the Mesopotamian basin (Figure 2), which is characterized by the presence of subsurface geological domes and structures, along with anticline folds [5]. The trend of the structures is toward NW-SE in the eastern part of the zone and N-S in the southern part, with some trending NE-SW (Figure 3) [6].

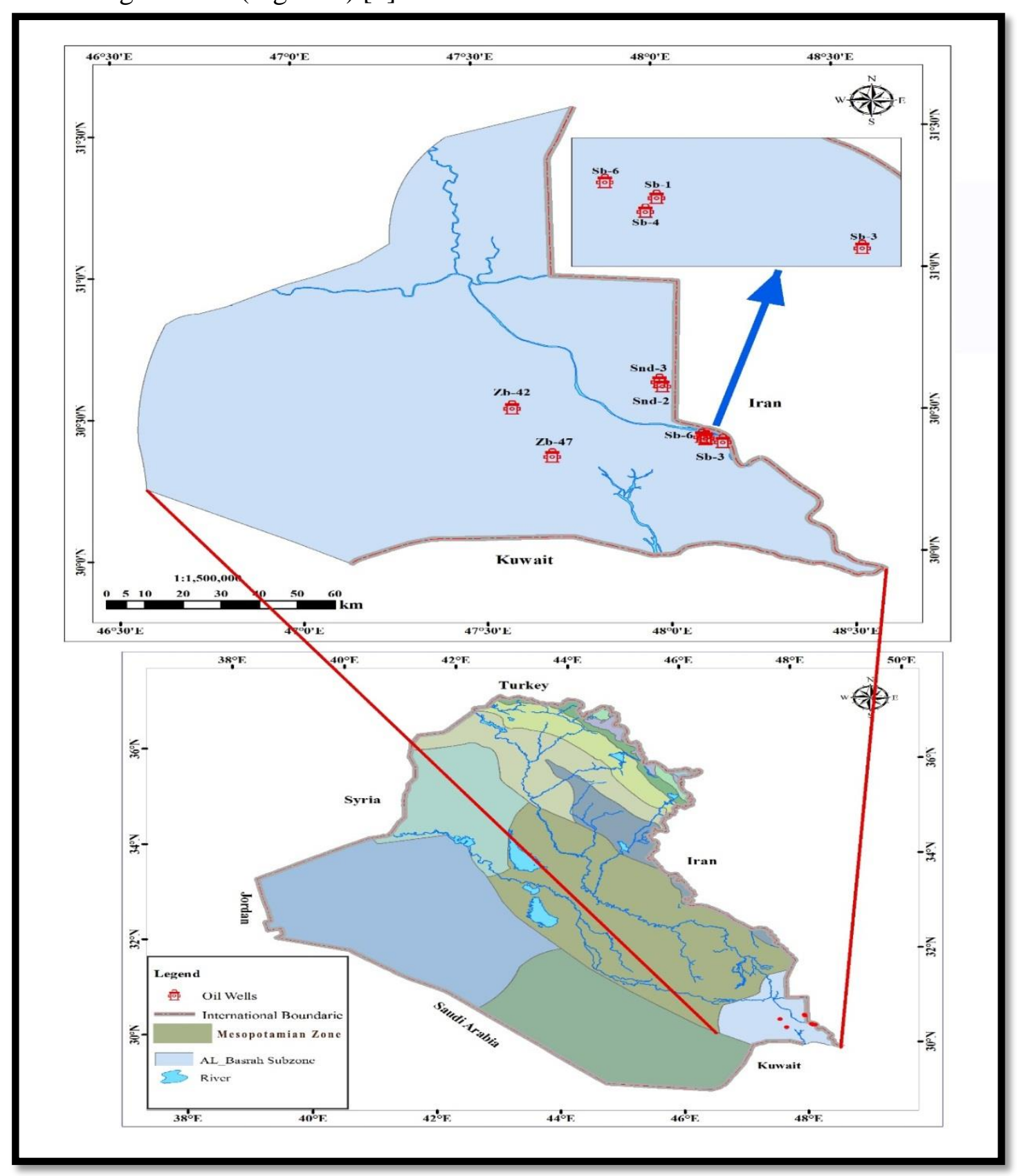

Figure 2-Tectonic and location map of the studied fields showing Mesopotamian Zone (ALBasrah Subzone), modified after [5]. 


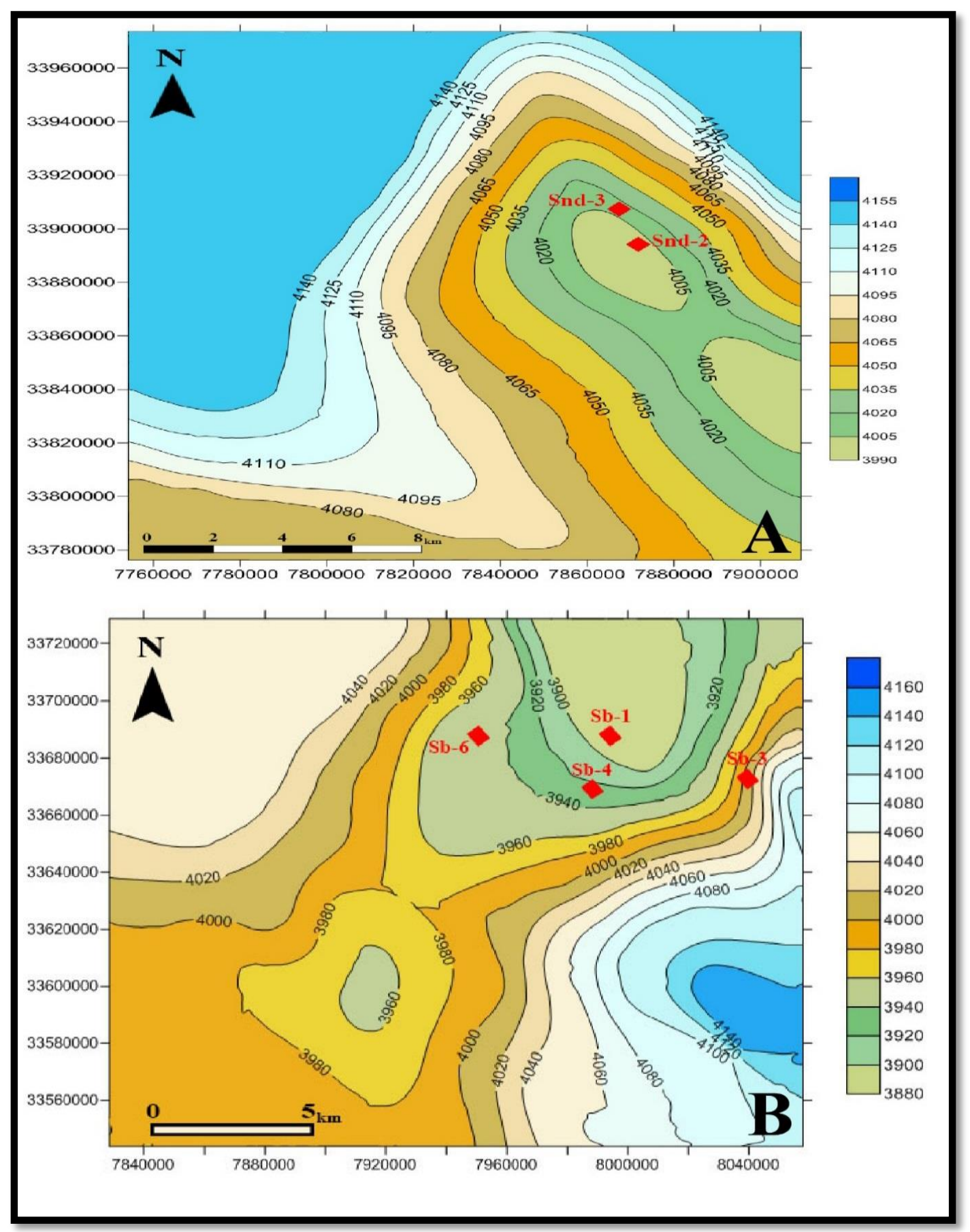

Figure -3 Structural contour map at top of Yamama Formation, Sindbad (A) and Siba (B) oilfields [7].

\section{b. Stratigraphy}

Yamama Formation was first described in Mesozoic Rocks in Saudi Arabia [8]. The authors stated that the Yamama Formation, as well as the Buaib and Sulaiy Formations, belong to the Thamama group. Another work [9] described and integrated the Yamama Formation with the Sulaiy Formation, which belongs to Late Berrisian-Valangenian. Yamama Formation is also conformable with the overlying and underlying Ratawi and Sulaiy Formations, respectively (Figure 4) [10]. 


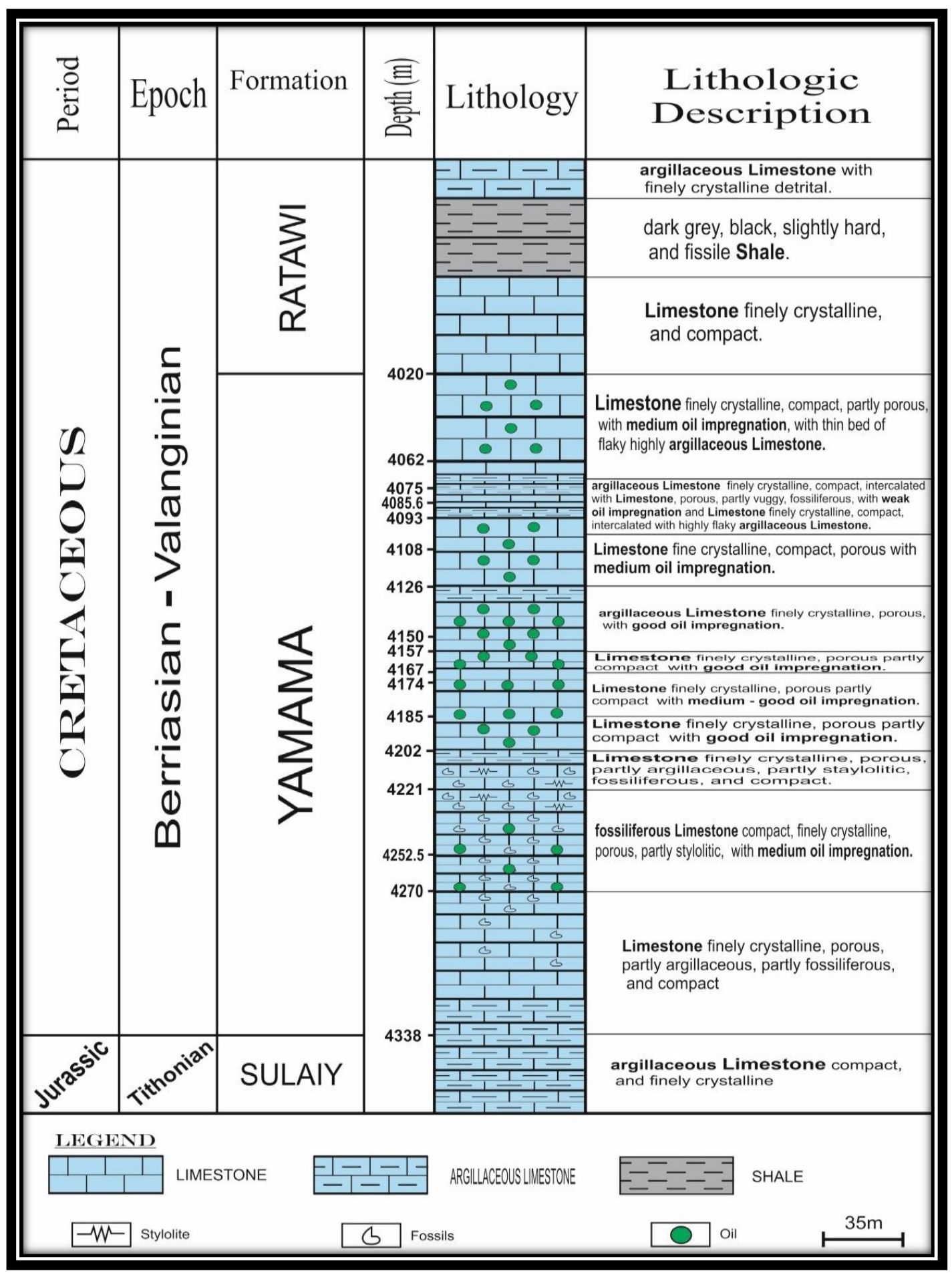

Figure -4 Stratigraphic column section of Yamama Formation well of Snd-2 with lithological description [11].

\section{Microfacies Analysis and Depositional Environment model}

The microscopic examination of Yamama Formation resulted in the description of several forms of microfacies in the oilfields studied. Microfacies were determined according to the depositional environmental. Five facies associations were recognized (Mid ramp, Open marine, Restricted marine, Shoal, and Lagoon). 
The carbonate ramp environments were previously divided [12, 13] into (1) inner ramp, (2) middle ramp, and (3) outer ramp. Early Cretaceous Yamama Formation was deposited in the Mesopotamian Basin, which is built on a gently dipping slope of the Arabian Platform and considered a passive margin on a ramp setting $[14,15]$. Yamama Formation in this study is characterized by absence of any reef margin development, lack of main slope break from shoreline to deeper water, and presence of high-energy grainstone facies. This evidence indicates a homoclinal ramp model as a depositional setting (Figure 5).

A mid-ramp facies association is distributed across all wells studied. It almost occurs in the middle to some upper parts without repetition in the succession of Yamama Formation. The large amounts of micrite in the mid-ramp environment are indicative for low energy deposition. Mid-ramp of Yamama Formation comprises mudstone and fossiliferous wackestone microfacies (Plate1.A and B).

An inner ramp composed of open and restricted marine, shoal, and lagoon facies associations was developed in Yamama Formation. Open and restricted marine and lagoon microfacies are rich in lime mud and dominated by benthic foraminifers, green algae, shell fragments, and debris echinoderms in the studied fields. The inner ramp comprises open marine environments with good water circulation, restricted-marine protected environments with restricted water circulation and relatively low to moderate energy, and open water circulation [12].

Open marine microfacies consists of bioclastic wackestone, bioclastic sponge spicule wackestone, and bioclastic echinoderms wackestone (Plate1.C and D). Skeletal grains consist mainly of sponge spicules with debris of echinoderms, algae, benthic foraminifera, miliolids, and shell fragments.

The dominated grains of restricted marine consist of diverse bioclasts algae and foraminifera (miliolids), with minor debris echinoderm and mollusca. Restricted marine microfacies are composed of bioclastic algal packstone, foraminiferal bioclastic wackestone, and bioclastic wackestone (Plate1.E and F).

The distribution of carbonate shoal is one of the variables that characterize inner ramp environments, with presence of peloids, ooids, and intraclasts in the microfacies of Yamama Formation. The shoal facies are deposited within high energy conditions [16]. Peloids are dominated in this environment, which is mainly comprised of five microfacies, namely pseudo-oolitic/peloidal grainstone, intraclasts/peloidal grainstone, bioclasts peloidal packstone, pseudo-oolitic/peloidal packstone, and ooidal/peloidal packstone (Plate 1.G and $\mathrm{H})$.

In the lower part of the Yamama Formation, the shoal facies association appears in varying thicknesses and then decreases to the upper part.

The lagoon environment is characterized by large amounts of lime mud with high diversity of large benthic foraminifera, green algae debris, boundstone, and transported peloids.

Lagoon facies association consists of Pseudocyclammina wackestone, Trocholina wackestone, foraminiferal packstone, bioclastic algal wackestone, and Lithocodium boundstone (Plate 1.I-J). 


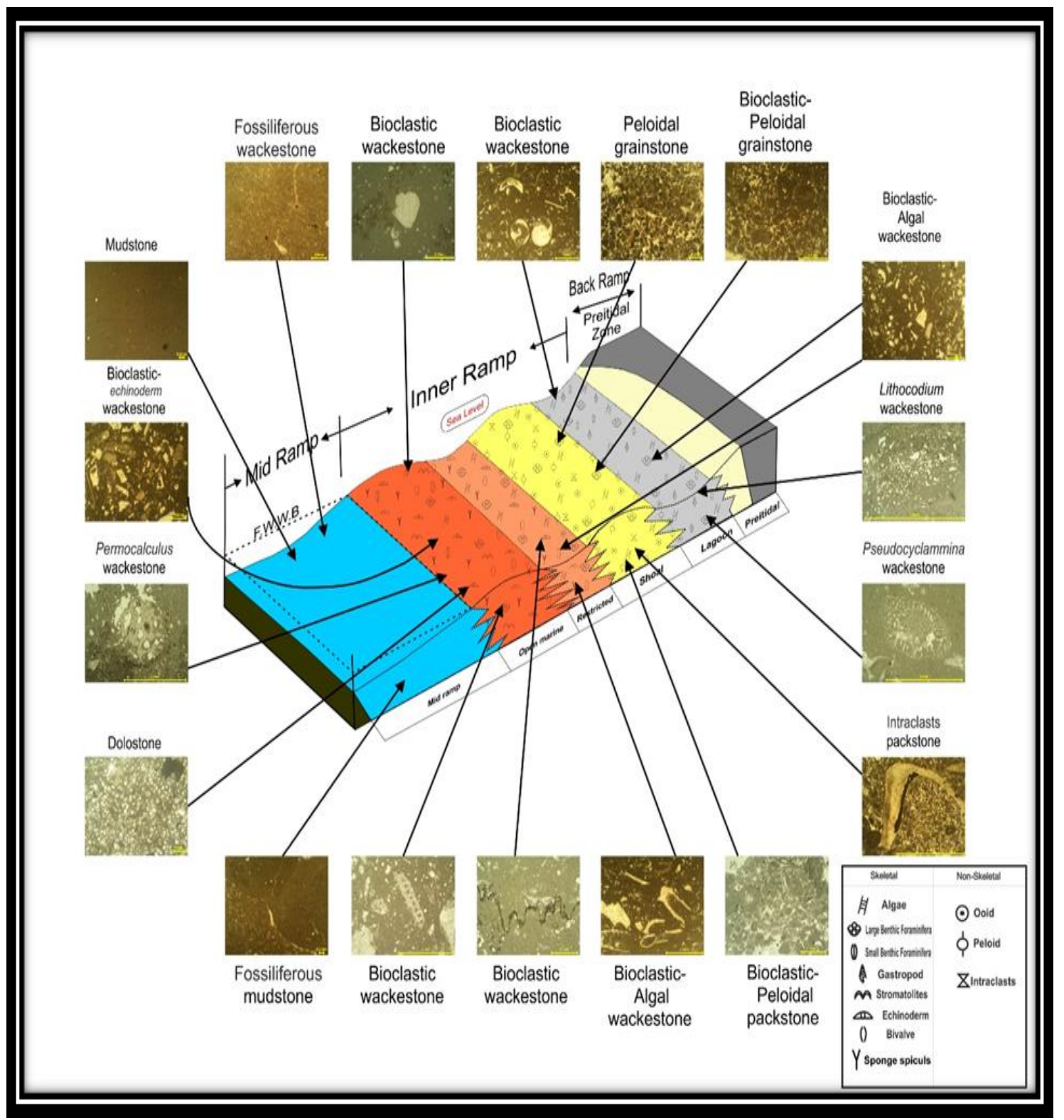

Figure 5-Depositional model of homoclinal carbonate ramp showing the approximate distribution of facies associations of Yamama Formation in the study area.

\section{Reservoir units classification}

An integrated interpretation of depositional environments and well logs constitutes a powerful tool for the prediction of reservoir distribution and formation evaluation.

Reservoirs are porous and permeable rock bodies that contain commercial amounts of hydrocarbons [1]. According to the available $\operatorname{logs}$ data for the Sindbad and Siba oilfields, there are six reservoir units that are distributed on the five wells of Yamama Formation. These are YA0, YA1, YA2, YB1, YB2 and YC [11]. This classification is supported by the output of present microfacies study.

\section{Reservoir Unit YA0}

This unit is located at the uppermost parts of the Yamama Formation. Its thickness ranges from 11.42 to $15.58 \mathrm{~m}$. The effective porosity is poor to fair $(6.4 \%)$, showing the weak petrophysical properties due to strong effects of the washout on the caliper log (Figures 6, 7, 8,9 and 10). The water saturation average of this unit is about $50 \%$. This unit consists of 
lagoonal facies, which includes wackestone with moldic and intraparticle pores, along with high to moderate clay content.

\section{Reservoir Unit YA1}

The thickness of this unit is $10-14 \mathrm{~m}$. The effective porosity is fair $(8.8 \%)$. Water saturation is about $40.8 \%$. This unit has good petrophysical properties due to low clay content and high porosity (Figures 6, 7, 8, 9 and 10). It is characterized by wackestone to packstone microfacies, indicating lagoonal environment represented by moldic and intraparticle pores.

\section{Reservoir Unit YA2}

The unit thickness ranges from 16 to $17.6 \mathrm{~m}$, which is significantly higher than that of unit YA1, but the petrophysical properties of the two units are generally relatively similar. The YA2 unit effective porosity is fair (8\%). The water saturation average is about $46 \%$, due to high clay content (Figsure 6, 7, 8, 9 and 10). It is represented by wackestone microfacies deposited in restricted environment that is characterized by moldic or isolated vug pores.

\section{Reservoir Unit YB1}

The thickness of this reservoir unit is $23.3-27.9 \mathrm{~m}$. It is characterized by low clay content and weak petrophysical properties, such as fair effective porosity $(6.8 \%)$, with water saturation average at around $46.8 \%$. The wells on the Sindbad oilfield show the lowest reservoir quality (Figures 6, 7, 8, 9 and 10). The wells of the Siba oilfield contain good reservoir characteristics. This unit, in terms of depositional environments, is interpreted as a restricted marine environment that includes intraparticle, moldic, and some interparticle pores.

\section{Reservoir Unit YB2}

The thickness of this unit is $27-43.6 \mathrm{~m}$. It shows good-excellent effective porosity with low water saturation. This unit was deposited in shoal environment. For this reasons, it is considered as one of the most important reservoir units for the Yamama Formation, within the Sindbad and Siba oilfields, in terms of reservoir quality, characterized by interparticle, interaparticle, and vug pores. The effective porosity is about $10.95 \%$, where the Sb-1 well has the largest effective porosity (16.7\%), while the average water saturation is about $28 \%$. The water saturation average of this unit is about 36.8\%, as shown in Figures 6, 7, 8, 9 and 10.

\section{Reservoir Unit YC}

This unit is located in the lower parts of the Yamama Formation. It is the thickest unit, reaching 33.5-140.7 $\mathrm{m}$. The unit has lowest petrophysical characteristics, due to poor effective porosity of about $6.8 \%$ that is recorded in the upper and mid parts of the unit. This unit contains compacted limestone rocks, as indicated by the increased density log values, accompanied by a decrease in the sonic $\log$ values (Figures 6, 7, 8, 9 and 10). This is due to the characteristics of the Mid-ramp depositional environment, that is associated with mudstone and wackestone microfacies and characterized by moldic and isolated vug pores. The average value of water saturation is about $62 \%$, where the highest value of saturation was in the Snd-3 well (95\%).

\section{Diagenesis Impact on Yamama Reservoir}

Diagenesis may enhance (preserve) or destroys reservoir quality by filling pore space with cementation or creating pore spaces by dissolution. Generally, carbonate rocks are characterized by heterogeneity. This heterogeneity is due to the chemical compound of carbonate rocks, i.e. $\mathrm{CaCO}_{3}$. This chemical compound makes the carbonate rocks more sensitive to the pore water chemistry (easy to be dissolved or easy to be precipitated), according to the thermodynamic, kinetic, ad hydrologic conditions [17]. Within Yamama Formation units, three main diagenetic processes are characterized. These are dissolution, cementation, and dolomitization.

The main diagenetic process that occurred in YA0, YA2, and YB1 is cementation. Cementation leads to filling pore spaces by cement and subsequently decreases the reservoir quality in terms of porosity and permeability (plate 1-H and I). In contrast, the main 
diagenetic process in YB2 reservoir unit is dissolution. Dissolution leads to creating pore spaces by dissolving calcium carbonate and subsequently leads to enhanced reservoir quality (plate 1-D and E).

Finally, the last main diagenetic process within Yamama reservoir units is dolomitization. Dolomitization may enhance or destroys pore spaces. In this study, dolomitization occludes pore space by filling the dolomite intercrystalline pores, but is uncommon in the formation succession (plate 1-A).

Plate -1

A. Fine grains in dolomitic mudstone affected by stylolites, mid ramp facies association (well Sb-3, 4047.5m, 10x.PPL).

B. Fossiliferous wackestone, consisting of lime-mud, mid ramp facies association (well Sb-6 4059.9m, 10x.XLL).

C. Bioclastic sponge spicule wackestone, Open marine facies association (well Snd-2, 4196.5m, 0.08x.PPL).

D. Bioclastic echinoderms wackestone, Open marine facies association in Inner Ramp with syntaxial cements (well Snd-2, 4196m, 0.08x.PPL).

E. Bioclastic wackestone, Restricted marine facies association (well Snd-2, 4196m, 0.08x.PPL).

F. Bioclastic algal wackestone, including vuggy pores and calcite cement, restricted facies association (well Snd-2, 4182m, 0.08x.PPL).

G. Peloidal/ooidal grainstone, consisting mainly of peloids covered by micritization and syntxial cements, Shoal facies association (well Snd-2, 4064.5m, 0.08x.PPL).

H. Intraclast peloidal grainstone, consists of shell fragment, benthic Foraminifera, Shoal facies association (well Snd-2, 4184m, 0.08x.PPL).

I. Foraminiferal packstone, Lagoon facies association, including syntaxial cement (well Snd-2, 4186m, 0.08x.PPL).

J. Boundstone, Lithocodium / Bacinella irregularis, including isolated vuggy pores, Lagoon facies association (well Snd-3, 4151.5m, 5x.PPL). 
Plate -1
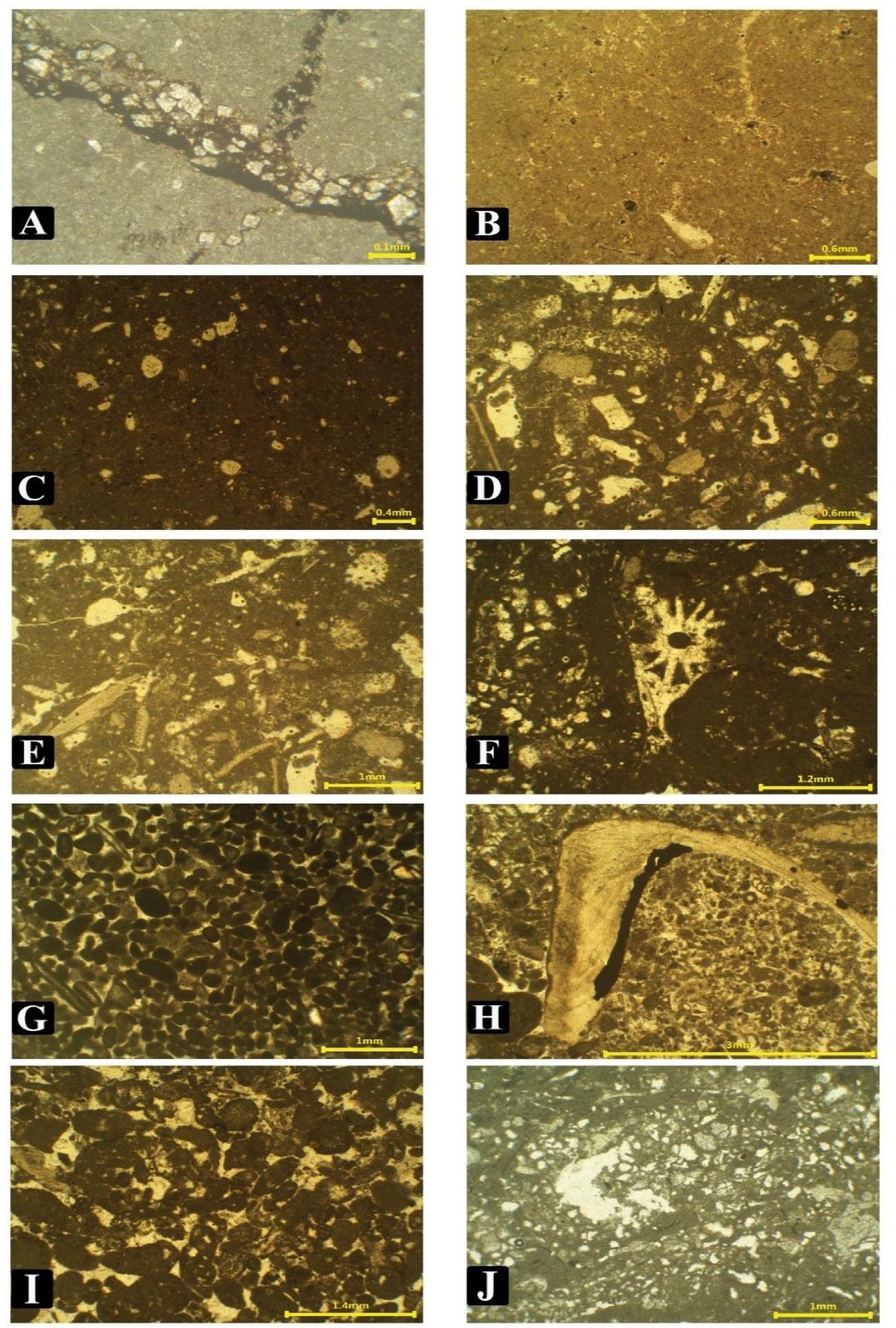


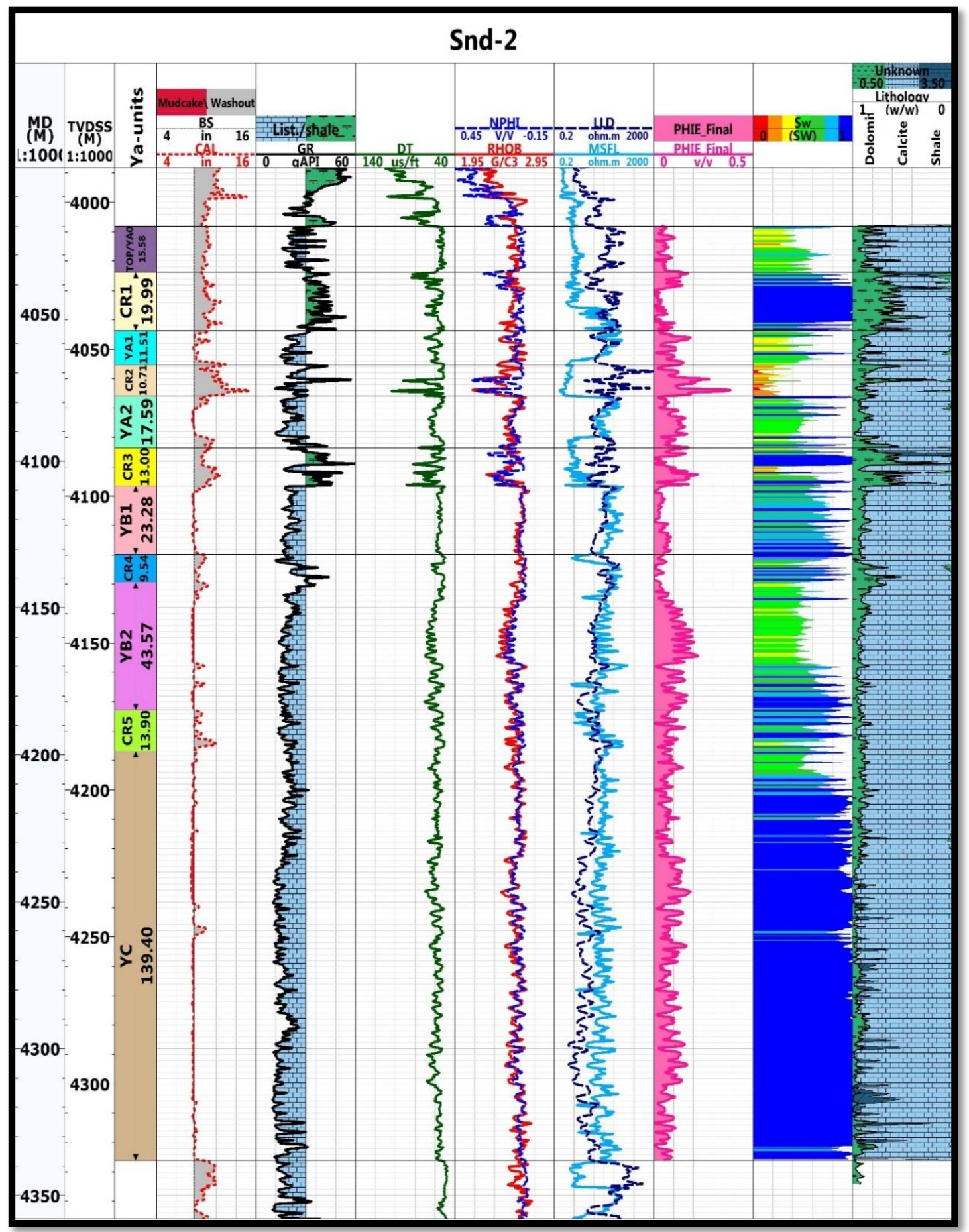

Figure 6-Computer Processed Interpretation (CPI) of Yamama Formation in Snd-2 well. 


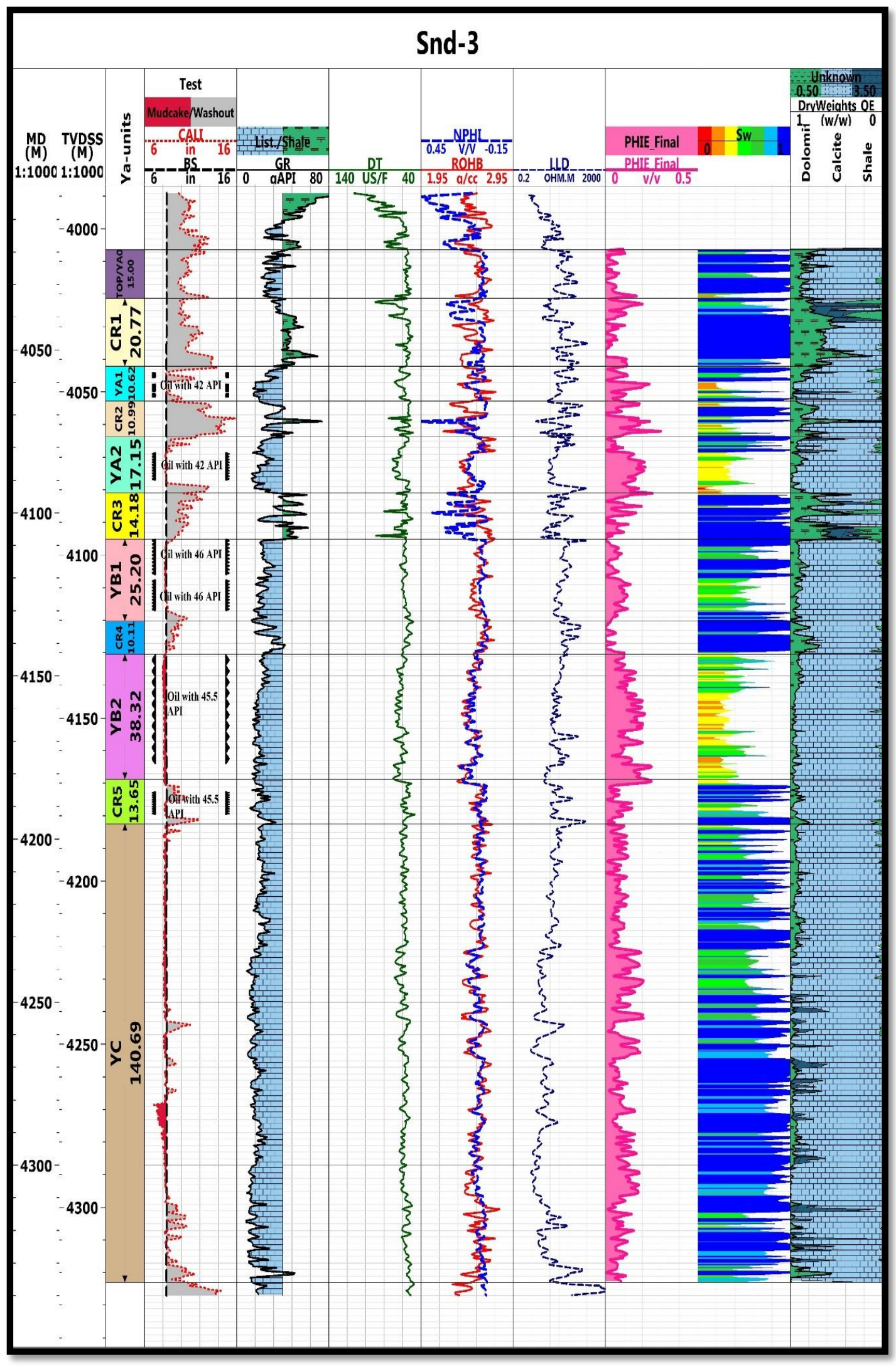

Figure 7-Computer Processed Interpretation (CPI) of Yamama Formation in Snd-3 well. 


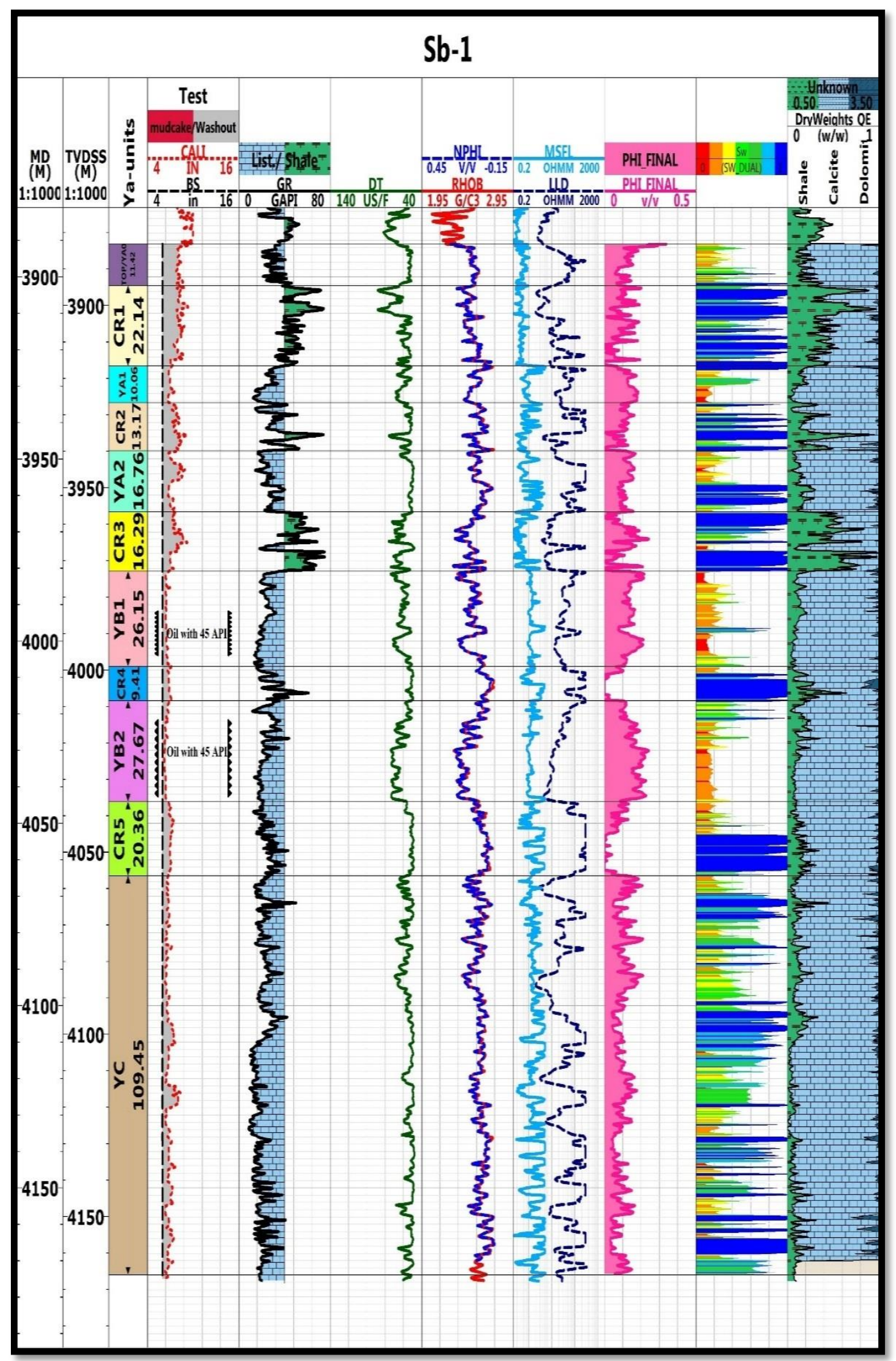

Figure 8 -Computer Processed Interpretation (CPI) of Yamama Formation in Sb-1 well. 


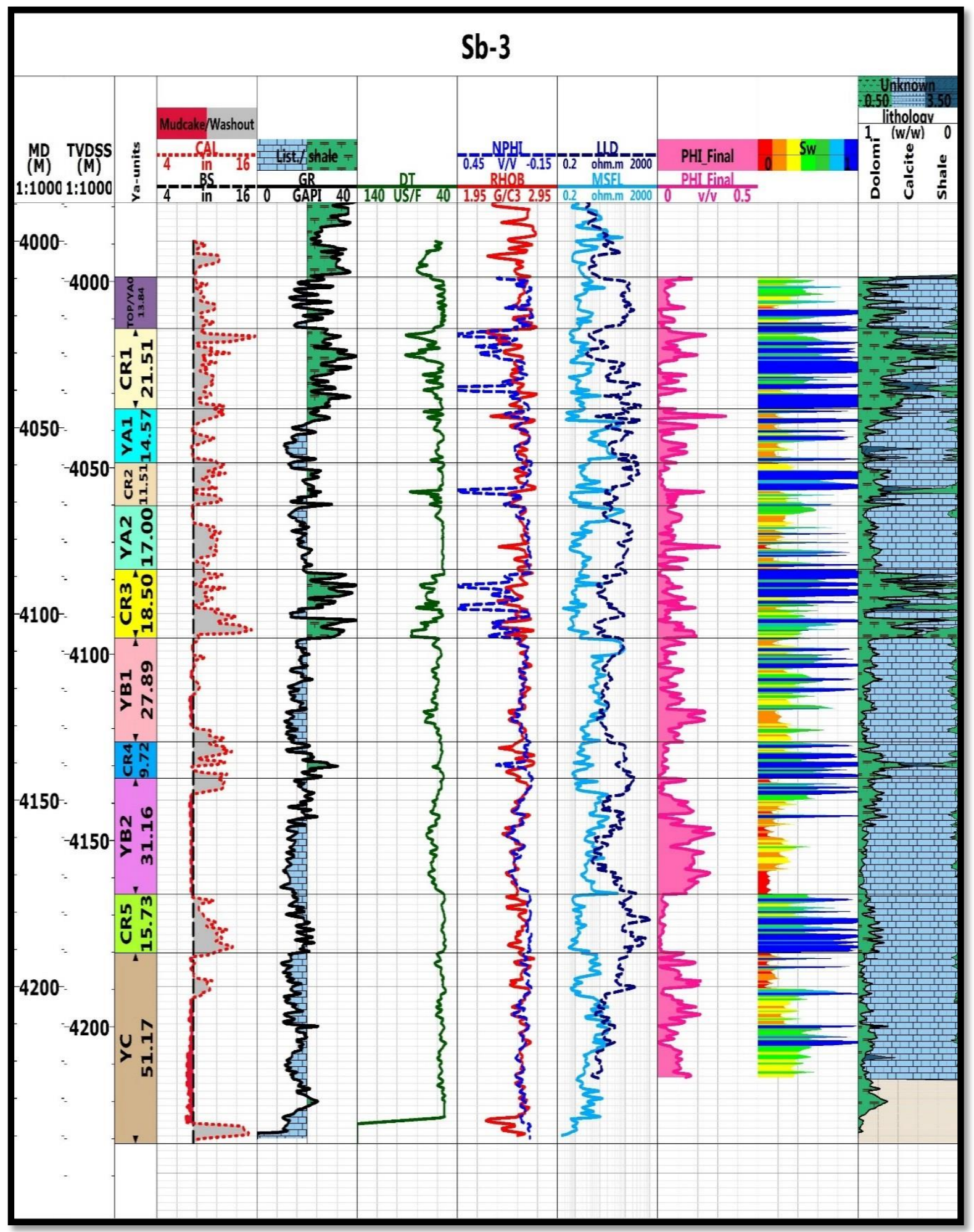

Figure -9 Computer Processed Interpretation (CPI) of Yamama Formation in Sb-3 well. 


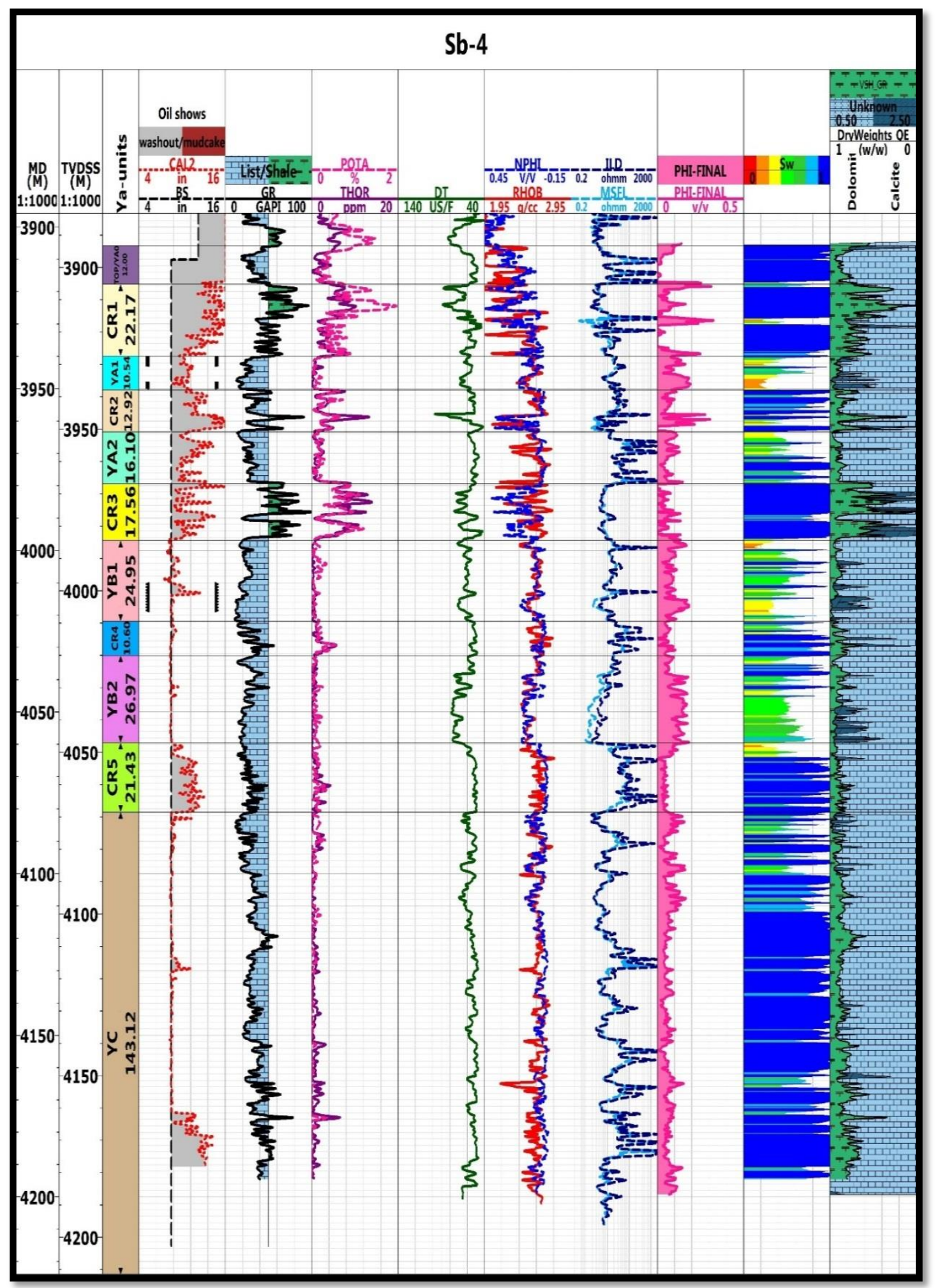

Figure 10-Computer Processed Interpretation (CPI) of Yamama Formation in Sb-4 well.

\section{Conclusions}

1. This study suggests that Yamama Formation was deposited within a homocline ramp environment. It is distinguished by mid and inner ramp settings, with mid-ramp microfacies being distributed across all wells studied. 
2. Grainstone, packstone, and wackestone microfacies are the most common textures determined within shoal, lagoon, and restricted marine environments. The Yamama Formation matrix consists of argillaceous and mud-supported lime.

3. The major diagenetic processes that influenced the microfacies of Yamama Formation were distinguished; the most common are cementation and dolomitization, but the latter is not continuous throughout the formation intervals.

4. Primary and secondary pores are common in reservoir facies, especially in the shoal environment.

5. Based on the results of CPI, the units YA1 and YB2 have the best reservoir properties. The YB2 unit is characterized by a good average effective porosity, low water saturation, good permeability, and large thickness, which renders it distinguished from other reservoir units.

\section{References}

[1] W. M. Ahr, Geology of Carbonate The Identifi cation, Description, and Characterization of Hydrocarbon Reservoirs in Carbonate Rocks. 2008.

[2] J. E. Fox and T. S. Ahlbrandt, Petroleum geology and total petroleum systems of the Widyan Basin and interior platform of Saudi Arabia and Iraq, vol. 2202. US Department of the Interior, US Geological Survey, 2002.

[3] Q. Abeed, A. J. Al-Khafaji, and R. Littke, "Source rock potential of the upper jurassic lower cretaceous succession in the southern mesopotamian basin, southern Iraq," J. Pet. Geol., vol. 34, no. 2, pp. 117-134, 2011.

[4] S. Z. Jassim and J. C. Goff, Geology of Iraq. DOLIN, sro, distributed by Geological Society of London, 2006.

[5] S. F. A. Fouad, "Tectonic map of Iraq, scale 1: 1000 000, 2012," Iraqi Bull. Geol. Min., vol. 11, no. 1, pp. 1-7, 2015.

[6] S. Z. Jassim, T. Buday, and I. Cicha, "Tectonic framework," Geol. Iraq. Czech Repub. Publ. by Dolin, Prague Morav. Museum, Brno, pp. 35-52, 2006.

[7] INOC, "Iraq National Oil Company (INOC) Case Study," vol. 4, pp. 6-13, 1978.

[8] M. Steineke and R. A. Bramkamp, "Mesozoic Rocks of Eastern Saudi-Arabia," In Aapg Bulletin-American Association of Petroleum Geologists, vol. 36, no. 5, p. 909, 1952.

[9] H. V Dunnington, "Mesozoic (cretaceous)," Lex. Stratigr. Int. Asie, Iraq 10a. Cent. Natl. la Rech. Sci. Paris, 1959.

[10]T. Buday, The regional geology of Iraq: stratigraphy and paleogeography, vol. 1. State Organization, 1980.

[11]C. Oil, Basrah, "Final geological report," 2015.

[12] T. P. Burchette and V. P. Wright, "Carbonate ramp depositional systems," Sediment. Geol., vol. 79, no. 1-4, pp. 3-57, 1992.

[13]E. Flügel, Microfacies of carbonate rocks: analysis, interpretation and application. Springer Science \& Business Media, 2010.

[14]F. N. Sadooni, "Stratigraphic sequence, microfacies, and petroleum prospects of the Yamama Formation, Lower Cretaceous, southern Iraq," Am. Assoc. Pet. Geol. Bull., vol. 77, no. 11, pp. 1971-1988, 1993.

[15]P. R. Sharland et al., "Arabian plate sequence stratigraphy, GeoArabia Spec," Publ., Bahrain Gulf Pet., vol. 2, 2001.

[16]M. E. Tucker, SEDIMENTARY PETROLOGY: An Introduction to the Origin of Sedimentary Rocks An Introduction to the Origin of Sedimentary Rocks. 2001.

[17] S. Boggs Jr and S. Boggs, Petrology of sedimentary rocks. Cambridge university press, 2009. 